\title{
Klasifikasi Sel Darah Putih dan Sel Limfoblas Menggunakan Metode Multilayer Perceptron Backpropagation
}

\author{
Apri Nur Liyantoko*1 ${ }^{*}$ Ika Candradewi ${ }^{2}$, Agus Harjoko ${ }^{3}$ \\ ${ }^{1}$ Program Studi Elektronika dan Instrumentasi, FMIPA, UGM, Yogyakarta, Indonesia \\ ${ }^{2,3}$ Departemen Ilmu Komputer dan Elektronika, FMIPA UGM, Yogyakarta, Indonesia \\ e-mail:*19apri.nur.l@mail.ugm.ac.id, ${ }^{2}$ ika.candradewi@ugm.ac.id, ${ }^{3}$ aharjoko@ugm.ac.id
}

\begin{abstract}
Abstrak
Leukemia merupakan salah satu penyakit kanker yang ada pada sel darah putih. Karakteristik dari penyakit ini ditandai dengan perkembangan sel darah putih tidak normal yang disebut limfoblas pada sumsum tulang belakang. Klasifikasi jenis-jenis sel darah dan perhitungan rasio jenis-jenis sel serta perbandingan dengan sel darah normal dapat menjadi subjek untuk mendiagnosa penyakit ini. Proses diagnosa dilakukan oleh pakar hematologi secara manual melalui citra mikroskopis. Pendekatan ini cenderung membutuhkan waktu yang lama dan hasil yang subjektif.

Penerapan Teknik pengolahan citra digital dan machine learning dalam proses pengklasifikasian sel darah putih bisa memberikan hasil yang lebih objektif. Dalam penelitian ini digunakan thresholding sebagai segmentasi serta metode multilayer perceptron perambatan balik dengan variasi ekstraksi fitur tekstural, geometri, dan warna. Hasil pengujian segmentasi pada penelitian ini sebesar $68,70 \%$. Sedangkan dalam pengujian klasifikasi menunjukkan bahwa kombinasi ekstraksi ciri GLCM 2 fitur, fitur geometri, dan fitur warna memberikan hasil yang terbaik. Pengujian ini menghasilkan nilai akurasi 91,43\%, presisi 50,63\%, sensitivity $56,67 \%, F_{1}$ Score $51,95 \%$, dan specitifity sebesar $94,16 \%$.
\end{abstract}

Kata kunci - leukemia, klasifikasi sel darah putih, multilayer perceptron, backpropagation

Leukemia is a type of cancer that is on white blood cell. This disease are characterized by abundance of abnormal white blood cell called lymphoblast in the bone marrow. Classification of blood cell types, calculation of the ratio of cell types and comparison with normal blood cells can be the subject of diagnosing this disease. The diagnostic process is carried out manually by hematologists through microscopic image. This method is likely to provide a subjective result and time-consuming.

The application of digital image processing techniques and machine learning in the process of classifying white blood cells can provide more objective results. This research used thresholding method as segmentation and multilayer method of back propagation perceptron with variations in the extraction of textural features, geometry, and colors. The results of segmentation testing in this study amounted to $68.70 \%$. Whereas the classification test shows that the combination of feature extraction of GLCM features, geometry features, and color features gives the best results. This test produces an accuration value $91.43 \%$, precision value of $50.63 \%$, sensitivity $56.67 \%$, F1Score $51.95 \%$, and specitifity $94.16 \%$.

Keywords - leukemia, white blood cell classification, multilayer perceptron, backpropagation

Received September 23 ${ }^{\text {th }}, 2019 ;$ Revised October $23^{\text {th }}, 2019 ;$ Accepted October $31^{\text {th }}, 2019$ 


\section{PENDAHULUAN}

Sel darah putih atau leukosit merupakan komponen penting yang berperan sebagai sistem imunitas dalam darah dan dikategorikan menjadi beberapa tipe, antara lain neutrofil (50$70 \%$ ), limfosit (25-30\%), monosit (3-9\%), eusonofil (0-5\%), basofil (0-1\%) dimana presentase tersebut merupakan rasio tipe sel darah putih yang sehat [1]. Leukemia merupakan salah satu penyakit kanker yang ada pada sel darah putih. Karakteristik dari penyakit ini ditandai dengan perkembangan sel darah putih yang tidak normal di sumsum tulang belakang tanpa menghambat pertumbuhan sel. Terdapat dua jenis leukemia yang umum diketahui yaitu Leukemia Limfosit Akut (LLA) yang mempengaruhi perkembangan sel limfosit dan Leukemia Mieloid Akut (LMA) yang mempengaruhi perkembangan sel mileoid (basofil, eosinofil, dan neutrofil) [2].

Di bidang hematologi dan infeksi penyakit, klasifikasi jenis-jenis darah dapat menjadi objek untuk mendiagnosa penyakit. Rasio jenis-jenis sel dihitung dan dibandingkan dengan keadaan normal, hasil yang diperoleh dapat mendeteksi kemungkinan suatu penyakit dari darah tersebut [3]. Selama ini klasifikasi jenis-jenis darah masih menggunakan metode tradisional yaitu dengan membandingkan rasio sel darah putih secara manual oleh pakar hematologi menggunakan mikroskop. Namun, metode ini membutuhkan waktu yang relatif lama dan memiliki prosedur yang kompleks.

Klasifikasi sel darah putih juga dapat dilakukan secara otomatis yaitu dengan metode pengolahan citra digital. Beberapa penelitian juga telah dilakukan, salah satunya adalah klasifikasi sel darah menggunakan classifier SVM dengan fitur warna dan bentuk [4]. Selain itu multilayer perceptron juga digunakan sebagai classifier dengan fitur LDP sebagai ekstraksi cirinya [5]. Metode multilayer perceptron sering diterapkan dalam dunia biomedis karena dianggap bagus dalam menganalisis data yang kompleks [3]. Sehingga diperlukan penelitian lebih lanjut untuk mengklasifikasikan sel darah putih dan sel limfoblas menggunakan metode multilayer perceptron dengan algoritme perambatan balik.

\section{METODE PENELITIAN}

\subsection{Analisis Sistem}

Sistem dibuat untuk mengklasifikasikan jenis sel darah putih dan sel limfoblas (sel acute lyphoblastic leukemia) dengan pengolahan citra digital. Klasifikasi dibedakan menjadi enam kelas yaitu basofil, eosinofil, limfosit, neutrofil, monosit, dan limfoblas. Hasil pengamatan direkam menggunakan kamera digital kemudian diproses melalui beberapa tahapan seperti pada Gambar 1.

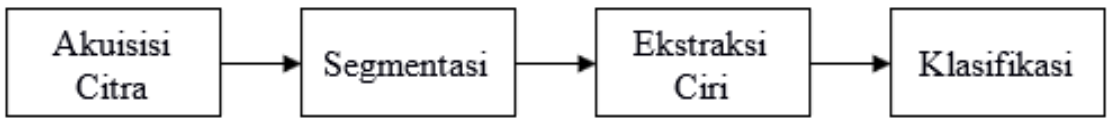

Gambar 1 Diagram blok sistem keseluruhan

Pengolahan citra sel darah dilakukan melalui beberapa tahapan. Tahapan pertama adalah segmentasi yang bertujuan untuk mendapatkan objek sel darah putih dan menghilangkan background citra yang tidak terpakai. Sel darah putih yang telah disegmentasi diekstraksi cirinya untuk mendapatkan fitur citra. Tahap selanjutnya adalah proses klasifikasi yang masukannya berupa nilai fitur yang telah didapatkan pada tahap ekstraksi ciri.

\subsection{Akuisisi Citra}

Tahap akuisisi citra dilakukan untuk memasukkan semua citra sel darah yang diperoleh dari rumah sakit Dr. Sardjito ke dalam sistem. Dataset diperoleh melalui proses scanning citra mikroskopis darah dalam bentuk citra RGB dan format data digital jpg. Dataset ini dibagi menjadi 4 macam berdasarkan perbedaan warna. Dataset pertama memiliki 12 


\subsection{Segmentasi Citra}

Tahap segmentasi merupakan tahapan untuk memotong (cropping) dan memisahkan objek dengan background. Proses segmentasi pada penelitian ini untuk mendapatkan citra sel darah putih (limfosit). Diagram alir tahap segmentasi dapat dilihat pada Gambar 2. Citra mikroskopis sel darah akan diubah ke dalam ranah warna HSV. Segmentasi dilakukan dengan memberikan threshold pada Channel $\mathrm{H}$. Nilai Hue paling cocok digunakan karena dapat membedakan objek sel darah putih dengan objek yang lain [6].

Untuk menghilangkan noise hasil dari thresholding, dilakukan operasi morfologi opening dan closing pada citra. Selanjutnya pelabelan sel darah putih diterapkan untuk memperoleh marker dari operasi distrance transform. Marker digunakan untuk membatasi objek yang akan diproses mengggunakan watershed transformation Algoritma ini berguna untuk memisahkan objek sel darah putih. Tahap terakhir adalah melakukan cropping pada ROI (Region of Interest). Hasil cropping ini adalah objek sel darah putih yang telah terpisah dari objek yang lain.

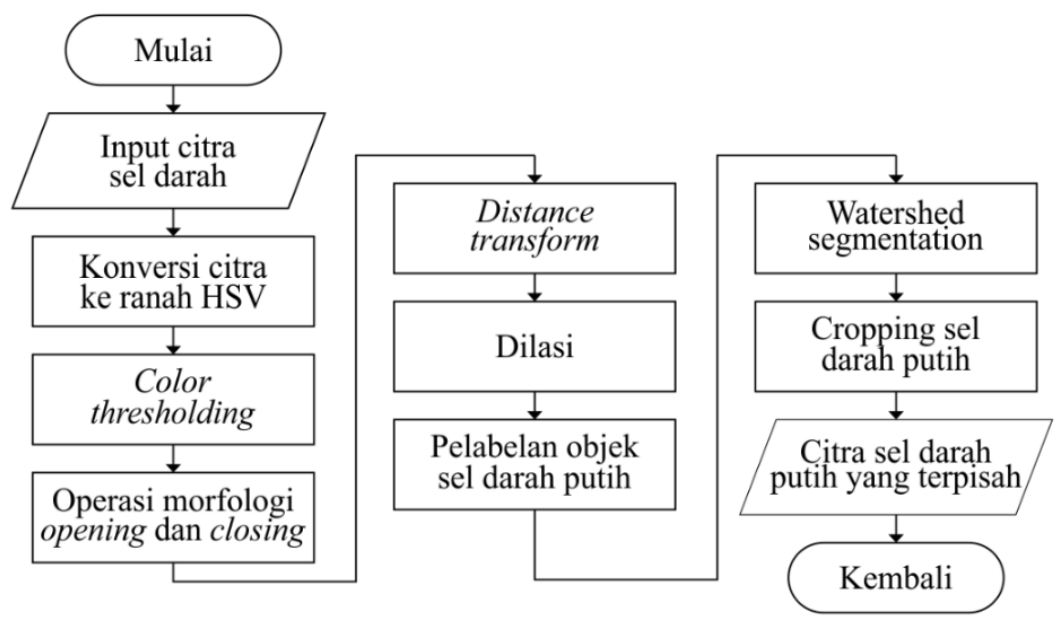

Gambar 2 Diagram alir segmentasi sel darah

\subsection{Ekstraksi Ciri}

Tahap ekstraksi ciri berfungsi untuk memperoleh informasi yang terkandung dari citra mikroskopis darah yang akan digunakan sebagai acuan untuk membedakan jenis citra sel darah dengan jenis citra sel darah lainnya. terdapat beberapa ciri yang diekstraksi antara lain adalah GLCM (Gray Level Co-occurent Matrix), LBP (Local Binary Pattern), LDP (Local Directional Pattern), fitur geometri, dan fitur warna.

\subsubsection{Gray Level Co-occurent Matriks}

Enam nilai tekstural GLCM digunakan sebagai ciri untuk mengenali objek khususnya sel darah. Nilai tekstural tersebut antara lain contrast, homogeneity, energy, dissimilarity, correlation, dan angular second moment. Perhitungan nilai tekstural ini diperoleh dari matriks kookurensi suatu citra [7].

- Contrast : merupakan variasi tingkat abu-abu lokal dalam Gray Level CO-Occurent Matriks. Ini dapat dianggap sebagai ketergantungan linear dari tingkat abu-abu dari piksel tetangga. Fitur ini dihitung seperti pada persamaan (1).

$$
\text { Contrast }=\sum_{i, j}|i-j|^{2} p(i, j)
$$

- Homogeneity: menunjukkan kehomogenan citra berderajat keabuan sejenis. Citra homogen akan memiliki harga homogenitas yang besar. Fitur ini dihitung seperti pada persamaan (2). 


$$
\text { Homogeneity }=\sum_{i, j} \frac{1}{1-(i-j)^{2}} p(i, j)
$$

- Energy : Energi menyatakan ukuran konsentrasi pasangan dengan intensitas keabuan tertentu pada matriks, dimana dapat dihitung seperti pada persamaan (3)

$$
\text { Energy }=\sum_{i, j} p(i, j)^{2}
$$

- Dissimilarity : merupakan ukuran yang mendefinisikan variasi pasangan tingkat keabuan suatu citra, dimana dapat dihitung seperti pada persamaan (4)

$$
\text { Dissimilarity }=\sum_{i, j}|i-j| p(i, j)
$$

- Correlation : Korelasi merupakan pengukuran linear tingkat keabuan antara piksel pada posisi relative yang telah ditentukan terhadap satu sama lain, dimana dapat dihitung seperti pada persamaan (5)

$$
\text { Correlation }=\frac{\sum_{i} \sum_{j}(i, j) p(i, j)-\mu_{x} u_{y}}{\sigma_{x} \sigma_{y}}
$$

- Angular second moment : mengukur keseragaman tingkat keabuan suatu piksel pada citra. Ketika piksel sangat mirip, maka nilai angular second moment akan semakin besar, dimana dapat dihitung seperti pada persamaan (6)

$$
A S M=\sum_{i, j} p^{2}(i, j)
$$

\subsubsection{Local Binary Pattern}

Local binary pattern merupakan salah satu operator untuk deskripsi tekstur yang berdasarkan pada perbedaan piksel pusat dengan piksel tetangganya [8]. Untuk mencari nilai LBP dapat dicari melalui persamaan (7).

$$
L B P_{P, R}=\sum_{n=0}^{P-1} s\left(g_{n}-g_{c}\right) 2^{n}, s(x)=\left\{\begin{array}{l}
1, x \geq 0 \\
0, x<0
\end{array}\right.
$$

\subsubsection{Local Directional Pattern}

LDP adalah pola tekstur skala abu-abu yang mencirikan struktur spasial tekstur gambar lokal. Operator LDP menghitung nilai respons tepi di kedelapan arah pada setiap posisi piksel dan menghasilkan kode dari besaran kekuatan relative [9]. Proses ekstraksi ciri LDP dari citra pertama adalah konvolusi antara citra dengan mask dari kirsch edge detector. Kirsch edge detector akan membadingkan delapan piksel ketetanggaan sehingga cenderung lebih akurat dibandingkan mask deteksi tepi lainnya. Perhitungan ciri LDP sesuai dengan Persamaan (8).

$$
L D P_{k}=\sum_{i=0}^{7} b_{i}\left(m_{i}-m_{i}\right) \times 2^{i}
$$

Image descriptor digunakan untuk merepresentasikan ciri LDP yang telah diekstaksi dari citra asal. Salah satunya adalah membuat suatu histogram. Perhitungan histogram ini sesuai dengan Persamaan (9).

$$
\begin{aligned}
& H(\tau)=\sum_{r=1}^{M} \sum_{c=1}^{N} f\left(L D P_{k}(r, c), \tau\right) \\
& F(a, \tau)=\left\{\begin{array}{l}
1 \quad a=\tau \\
0 \text { otherwise }
\end{array}\right.
\end{aligned}
$$

\subsubsection{Fitur Geometri dan Fitur Warna}

Beberapa fitur geometri dan warna digunakan sebagai fitur tambahan untuk ekstraksi ciri. area, perimeter, rectangularity, circularity, standart deviation, dan mean. Fitur geometri akan dikonversi kedalam ranah grayscale untuk dicari konturnya terlebih dahulu. Sedangkan fitur warna menggunakan ranah RGB (3 channel) untuk mencari nilai mean dan standard deviation tiap channel. Perhitungan fitur geometri dan warna dapat dilihat pada Tabel 1. 
Tabel 1 jenis fitur geometri dan warna

\begin{tabular}{|l|c|}
\hline \multicolumn{1}{|c|}{ Jenis Ciri } & Rumus \\
\hline Area & $A=\frac{1}{n \cdot m} \sum_{x=0}^{m-1} \sum_{\substack{n-1 \\
=0}}^{n-f}[i(x, y) \mid i(x, y)$ \\
\hline Perimeter & $P=A-(A \theta B)$ \\
\hline Rectangularity & $R=\frac{m * n}{A}$ \\
\hline
\end{tabular}

Tabel 1 (Lanjutan)

\begin{tabular}{|l|c|}
\hline Circularity & $c=\frac{P}{A}$ \\
\hline Aspect ratio & $R=\frac{|m|}{n}$ \\
\hline Mean & $\overline{M_{n}}=\frac{\sum_{x} \sum_{y} M_{n}(x, y)}{n}$ \\
\hline $\begin{array}{l}\text { Standard } \\
\text { deviation }\end{array}$ & $\overline{S M_{n}}=+\sqrt{\frac{\sum_{x} \sum_{y}\left(M_{n}(x, y)-\overline{M_{n}}\right)^{2}}{n-1}}$ \\
\hline
\end{tabular}

\subsection{Klasifikasi}

Sistem ini digunakan untuk mengklasifikasikan lima jenis sel darah putih yang berupa basofil, eosinofil, neutrofil, monosit, limfosit, serta satu jenis sel acute lymphoblastic leukemia yang disebut sel limfoblas. Pengklasifikasian dilakukan dengan menggunakan metode jaringan syaraf tiruan arsitektur multilayer perceptron dengan algoritma perambatan balik. Kinerja klasifikasi dari jaringan multilayer perceptron akan sangat bergantung pada struktur jaringan dan algoritma pelatihan. Jaringan ini memiliki input berupa ciri hasil ekstraksi fitur dari citra sedangkan outputnya sebanyak enam buah sebagai klasifikasi enam buah sel darah putih dan sel limfoblas. Penentuan jumlah node hidden layer yang dihitung berdasarkan 2/3 jumlah node masukan ditambah jumlah node keluaran [10].

Pada penelitian ini, dicari model terbaik dari kombinasi fitur GLCM. Kombinasi ini berdasarkan jumlah fitur pada GLCM yaitu kombinasi 2 fitur, 4 fitur, dan 6 fitur. Selain itu digunakan variasi learning rate yang terdiri dari $1,0.5,0.1,0.05,0.01,0,005$, dan 0.001 . Sehinsgga akan diperoleh beberapa model dari proses pelatihan. Performa model kemudian bisa dicari dengan melihat nilai akurasi pada proses $k$-fold cross validation, dimana pada penelitian ini menggunakan 10 fold.

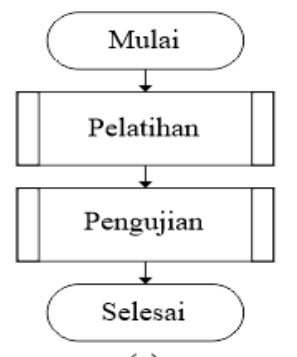

(a)
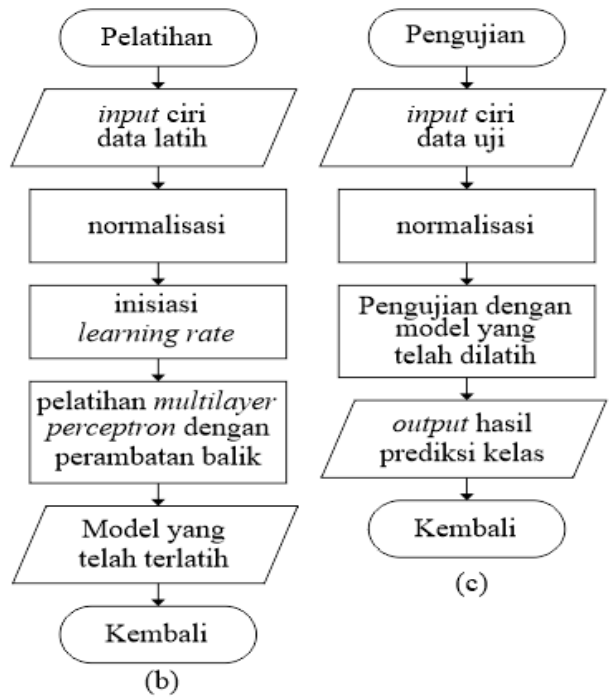

(c)

(b)

Gambar 3 (a) Diagram alir proses klasifikasi (a) pelatihan (b) pengujian 
Model dengan kombinasi fitur GLCM dan learning rate terbaik kemudian akan digunakan sebagai model untuk pengujian terhadap data uji. Diagram alir proses pengujian multilayer perceptron perambatan balik dengan variasi fitur ditunjukkan pada Gambar 3. Selain itu kombinasi fitur terbaik GLCM akan ditambah dengan fitur lainnya seperti LBP, LDP, fitur geometri, dan fitur warna yang modelnya akan diuji pada data uji.

2.6 Evaluasi Kinerja Sistem

Analisis dan pengujian sistem dilakukan untuk mengetahui performa sistem yang telah dibuat dalam mengklasifikasikan objek terhadap data uji. Pada evaluasi kinerja menggunakan confusion matrix yang berdasarkan nilai true positive, true negative, false positive, dan false negative. Dari hasil confussion matrix diperoleh performa sistem yang dihitung sesuai dengan persamaan (1) accuracy, persamaan (2) precission, persamaan (3) specitifity, persamaan (4) sensitivity, dan persamaan (5) $F_{1} S c o r e$.

$$
\begin{aligned}
& \text { Accuracy }=\frac{T P+T N}{T P+T N+F P+F N} \times 100 \% \\
& \text { Precision }=\frac{T P}{T P+F P} \times 100 \% \\
& \text { Specificity }=\frac{T N}{T N+F P} \times 100 \% \\
& \text { Sensitivity }=\frac{T P}{T P+F N} \times 100 \% \\
& F_{l} \text { Score }=2 \cdot \frac{\text { Presisi.Sensitivity }}{\text { Presisi+Sensitivity }} \times 100 \%
\end{aligned}
$$

\section{HASIL DAN PEMBAHASAN}

Bab ini menjelaskan tentang hasil dari implementasi sistem klasifikasi sel darah putih dan sel limfoblas menggunakan metode multilayer perceptron algoritma backpropagation. Hasil ini berupa performa kinerja sistem dalam menguji data uji yang diimplementasikan seluruhnya menggunakan Bahasa Python.

\subsection{Segmentasi Sel Darah Putih}

Pengujian segmentasi dilakukan pada empat dataset citra darah yang memiliki warna yang berbeda. Perbedaan warna ini tiimbul karena perbedaan teknik pengambilan sampel darah oleh ahli dari rumah sakit. Dataset pertama memiliki 125 citra mikroskopis darah dengan total sel darah putih sebanyak 259 sel. Dataset kedua memiliki 107 citra mikroskopis darah dengan total sel darah putih sebanyak 133 sel. Sedangkan Dataset ketiga memiliki 239 citra mikroskopis darah dengan total sel darah putih sebanyak 300 sel dan Dataset keeempat memiliki 191 citra mikroskopis darah dengan total sel darah putih sebanyak 251 sel. Hasil pengujian berupa nilai true positive, true negative, false positive, dan false negative seperti pada Tabel 2.

Tabel 2 Performa pengujian segmentasi dataset

\begin{tabular}{|c|c|c|c|c|}
\hline Dataset & True Positive & False Negative & True Negative & False Positive \\
\hline 1 & 201 & 58 & 0 & 49 \\
\hline 2 & 92 & 41 & 0 & 26 \\
\hline 3 & 267 & 29 & 0 & 79 \\
\hline 4 & 229 & 22 & 0 & 31 \\
\hline Total & 789 & 154 & 0 & 185 \\
\hline
\end{tabular}

Performa akurasi segmentasi masing-masing dataset berbeda-beda. Segmentasi pada dataset pertama sebesar $65,26 \%$ dan hasil pengujian segmentasi dataset 2 sebesar $57,86 \%$. Sedangkan pengujian untuk dataset 3 dan dataset 4 berturut-turut sebesar 70,45\% dan 81,21\%. Sehingga rata-rata akurasi pengujian pada seluruh dataset sebesar $68,70 \%$ dimana terdapat 789

IJEIS Vol. 9, No. 2, October 2019 : 173 - 182 
sel dapat tersegmen dengan baik dan 185 objek selain sel darah putih ikut tersegmentasi dari total 943 sel darah putih.

\subsection{Pelatihan Klasifikasi Sel Darah Putih}

Citra hasil segmentasi yang terdiri dari enam kelas kemudian digunakan sebagai data latih dan data uji pada proses klasifikasi. Persebaran jumlah sel yang tidak seimbang membuat proses pelatihan untuk memprediksi kelas sel menjadi kurang maksimal. Untuk mengurangi masalah ini, dilakukan proses undersampling pada kelas limfoblas, neutrofil, dan limfosit. Sehingga dari 789 sel dilakukan undersampling dengan persebaran data seperti pada Tabel 3.

Tabel 3 Persebaran dataset tiap kelas

\begin{tabular}{|c|c|c|c|c|c|c|}
\hline Dataset & limfoblas & neutrofil & limfosit & basofil & monosit & eosinofil \\
\hline data latih & 90 & 90 & 90 & 4 & 14 & 7 \\
\hline data uji & 10 & 10 & 10 & 1 & 2 & 2 \\
\hline
\end{tabular}

Performa tahap pelatihan dievaluasi dengan metode stratified kfold cross validation dengan $\mathrm{k}=10$ untuk mendapatkan nilai validasi akurasi model terbaik. Dalam penelitian ini, terdiri dari tiga buah pelatihan. Pelatihan pertama menggunakan variasi dua fitur GLCM, pelatihan kedua dengan variasi empat fitur GLCM sementara pelatihan ketiga menggunkana variasi enam fitur GLCM. Setiap pelatihan menggunakan fungsi aktifasi logistic sigmoid dengan iterasi maksimal 1000 kali serta memiliki 7 variasi learning rate.

Variasi dua buah fitur GLCM dengan learning rate 1 memiliki akurasi data latih yang cenderung sama sebesar 30,57\%. Untuk learning rate 0,5, akurasi tidak memiliki perubahan yang signifikan pada semua sudut GLCM. Sedangkan untuk learning rate dibawah 0,5 memiliki hasil akurasi yang bervariasi. Rata-rata hasil akurasi tertinggi terdapat pada learning rate 0,05 untuk semua sudut. Akurasi tertinggi pada GLCM sudut 0 sebesar 55,58\% dengan variasi fitur correlation dan asm. GLCM sudut 45 memiliki akurasi tertinggi sebesar 55,12\%. Sedangkan untuk GLCM dengan sudut 90 memiliki akurasi tertinggi sebesar 54,12\% dengan variasi fitur correlation dan angular second moment. dan GLCM dengan sudut 135 memiliki akurasi tertinggi sebesar 54,07 dengan variasi fitur contrast dan homogeneity.

Variasi empat buah fitur GLCM dengan learning rate 1 memiliki akurasi data latih yang cenderung sama sebesar $30,57 \%$. Untuk learning rate 0,5 , akurasi tidak memiliki perubahan yang signifikan pada semua sudut GLCM. Sedangkan untuk learning rate dibawah 0,5 memiliki hasil akurasi yang bervariasi. Hasil akurasi tertinggi terdapat pada learning rate 0,05 pada semua sudut. GLCM sudut 0 memiliki akurasi tertinggi sebesar 54,11\% dengan variasi fitur dissimilarity, energy, correlation, dan asm. Untuk GLCM sudut 45, akurasi tertinggi berada pada fitur contrast, homogeneity, dissimilarity, dan correlation sebesar 55,12\%. GLCM sudut 90 memiliki akurasi tertinggi sebesar 51,85\% dengan variasi fitur contrast, homogeneity, dissimilarity, dan angular second moment. Sedangkan GLCM sudut 135 memiliki akurasi tertinggi sebesar $52,51 \%$ dengan variasi fitur contrast, homogeneity, dissimilarity, dan correlation.

Sedangkan Hasil pelatihan GLCM enam fitur memiliki akurasi tertinggi pada 0 sebesar $51,79 \%$ dengan learning rate 0,1. sedangkan untuk GLCM 45, akurasi tertinggi berada pada learning rate 0,1 sebesar 51,11\%. Pelatihan GLCM sudut 90 memiliki akurasi tertinggi sebesar $51,1 \%$ dengan learning rate 0,001 . Untuk pelatihan GLCM sudut 135, akurasi tertinggi didapat pada learning rate 0,005 sebesar $50 \%$

Dari evaluasi pelatihan yang telah dilakukan, diperoleh performa akurasi terbaik pada variasi GLCM dengan dua fitur yaitu correlation dan angular second moment. Hasil performa ini sebesar 55,58\% pada sudut 0 dengan learning rate sebesar 0,05 . 


\subsection{Pengujian Klasifikasi Sel Darah Putih}

Model terbaik dari pelatihan GLCM digunakan sebagai dasar evaluasi pada data uji. Proses pelatihan juga menggunakan model yang telah ditambahkan beberapa fitur, antara lain LDP, LBP, fitur geometri, dan fitur warna.

\subsubsection{Klasifikasi dengan GLCM}

Pengujian dilakukan dengan model yang memiliki masukan GLCM berupa fitur correlation dan angular second moment. Model ini dievaluasi pada data uji dan dan diperoleh hasil confussion matrix dari model ini yang ditunjukkan pada Tabel 4.

Tabel 4 Confussion Matriks Model GLCM

\begin{tabular}{|c|c|c|c|c|c|c|c|}
\hline \multicolumn{2}{|c|}{} & \multicolumn{7}{c|}{ Prediksi } \\
\cline { 3 - 9 } \multicolumn{2}{c|}{} & Basofil & Eosinofil & Limfoblas & Limfosit & Monosit & Neutrofil \\
\hline \multirow{4}{*}{ Label } & Basofil & 0 & 0 & 0 & 0 & 0 & 1 \\
\cline { 2 - 9 } & Eosinofil & 0 & 0 & 0 & 0 & 0 & 2 \\
\cline { 2 - 9 } & Limfoblas & 0 & 0 & 7 & 3 & 0 & 0 \\
\cline { 2 - 9 } & Limfosit & 0 & 0 & 4 & 3 & 0 & 3 \\
\cline { 2 - 8 } & Monosit & 0 & 0 & 1 & 1 & 0 & 0 \\
\cline { 2 - 8 } & Neutrofil & 0 & 0 & 1 & 1 & 0 & 8 \\
\hline
\end{tabular}

\subsubsection{Klasifikasi dengan GLCM dan LBP}

Pengujian dilakukan dengan model yang memiliki input GLCM dengan dua fitur berupa fitur correlation dan angular second moment, serta input Local Binary Pattern yang memiliki 10 fitur. Model ini kemudian dievaluasi dengan data uji dan diperoleh hasil confussion matrix seperti pada Tabel 5 .

Tabel 5 Confussion Matriks Model GLCM dan LBP

\begin{tabular}{|c|c|c|c|c|c|c|c|}
\hline \multicolumn{2}{|c|}{} & \multicolumn{7}{c|}{ Prediksi } \\
\cline { 3 - 9 } & Basofil & Eosinofil & Limfoblas & Limfosit & Monosit & Neutrofil \\
\hline \multirow{4}{*}{ Label } & Basofil & 0 & 0 & 0 & 1 & 0 & 0 \\
\cline { 2 - 8 } & Eosinofil & 0 & 0 & 0 & 2 & 0 & 0 \\
\cline { 2 - 8 } & Limfoblas & 0 & 0 & 7 & 2 & 0 & 1 \\
\cline { 2 - 8 } & Limfosit & 0 & 0 & 0 & 8 & 1 & 1 \\
\cline { 2 - 8 } & Monosit & 0 & 0 & 0 & 1 & 0 & 1 \\
\cline { 2 - 8 } & Neutrofil & 0 & 0 & 0 & 0 & 0 & 10 \\
\hline
\end{tabular}

\subsubsection{Klasifikasi dengan GLCM dan LDP}

Pengujian dilakukan dengan model yang memiliki input GLCM dengan dua fitur berupa fitur correlation dan angular second moment, serta input Local Directional Pattern yang memiliki 56 fitur. Model ini kemudian dievaluasi dengan data uji dan diperoleh hasil confussion matrix seperti pada Tabel 6 .

Tabel 6 Confussion Matriks Model GLCM dan LDP

\begin{tabular}{|c|c|c|c|c|c|c|c|}
\hline \multicolumn{2}{|c|}{} & \multicolumn{7}{c|}{ Prediksi } \\
\cline { 2 - 9 } \multicolumn{2}{c|}{} & Basofil & Eosinofil & Limfoblas & Limfosit & Monosit & Neutrofil \\
\hline \multirow{4}{*}{ Label } & Basofil & 0 & 0 & 0 & 1 & 0 & 0 \\
\cline { 2 - 9 } & Eosinofil & 0 & 0 & 0 & 1 & 1 & 0 \\
\cline { 2 - 9 } & Limfoblas & 0 & 0 & 9 & 1 & 0 & 0 \\
\cline { 2 - 8 } & Limfosit & 0 & 1 & 2 & 6 & 0 & 1 \\
\cline { 2 - 8 } & Monosit & 0 & 0 & 0 & 1 & 1 & 0 \\
\cline { 2 - 8 } & Neutrofil & 1 & 4 & 0 & 1 & 0 & 4 \\
\hline
\end{tabular}




\subsubsection{Klasifikasi dengan GLCM, Fitur Geometri dan Fitur Warna}

Pengujian dilakukan dengan model yang memiliki input GLCM dengan dua fitur berupa fitur correlation dan angular second moment, kemudian ditambah dengan ciri geometri yang terdiri dari area, perimeter, aspect ratio, rectangularity, dan circularity, serta ciri warna 3 channel berupa mean dan standard deviation. Model ini kemudian dievaluasi dengan data uji dan diperoleh hasil confussion matrix seperti pada Tabel 7.

Tabel 7 Confussion Matriks Model GLCM, Fitur Geometri, dan Fitur Warna

\begin{tabular}{|c|c|c|c|c|c|c|c|}
\hline \multicolumn{2}{|c|}{} & \multicolumn{7}{c|}{ Prediksi } \\
\cline { 2 - 8 } \multicolumn{1}{|c|}{} & Basofil & Eosinofil & Limfoblas & Limfosit & Monosit & Neutrofil \\
\hline \multirow{4}{*}{ Label } & Basofil & 0 & 0 & 0 & 0 & 0 & 1 \\
\cline { 2 - 8 } & Eosinofil & 0 & 0 & 0 & 0 & 0 & 2 \\
\cline { 2 - 8 } & Limfoblas & 0 & 0 & 8 & 1 & 0 & 1 \\
\cline { 2 - 8 } & Limfosit & 0 & 0 & 1 & 6 & 1 & 2 \\
\cline { 2 - 8 } & Monosit & 0 & 0 & 0 & 0 & 2 & 0 \\
\cline { 2 - 8 } & Neutrofil & 0 & 0 & 0 & 0 & 0 & 10 \\
\hline
\end{tabular}

\subsection{Performa Klasifikasi}

Evaluasi sistem untuk klasifikasi sel darah putih dilakukan berdasarkan confussion matriks yang telah diperoleh sesuai dengan persamaan (1), persamaan (2), persamaan (3), persamaan (4), dan persamaan (5). Perbandingan nilai evaluasi sistem secara keseluruhan dapat dilihat pada tabel 8. Nilai evaluasi tersebut juga dibandingkan dengan penelitian [5] yang menggunakan fitur local directional pattern serta penelitian [11] yang menggunakan fitur bentuk dan warna. Terlihat bahwa GLCM dengan fitur correlation dan angular second moment ditambah dengan fitur warna dan geometri memiliki performa yang paling baik.

Tabel 8 Hasil Performa Sistem

\begin{tabular}{|l|l|l|l|l|l|}
\hline Jenis Fitur & Akurasi & Presisi & Sensitivity & F1 Score & Specificity \\
\hline$G L C M$ & $83,81 \%$ & $24,75 \%$ & $30 \%$ & $26,81 \%$ & $88,67 \%$ \\
\hline$G L C M+$ LBP & $90,48 \%$ & $39,01 \%$ & $41,67 \%$ & $39,33 \%$ & $93,49 \%$ \\
\hline$G L C M+$ LDP & $85,71 \%$ & $44,39 \%$ & $40 \%$ & $41,03 \%$ & $91,15 \%$ \\
\hline $\begin{array}{l}G L C M+\text { Fitur } \\
\text { Warna + Geometri }\end{array}$ & $91,43 \%$ & $50,63 \%$ & $56,67 \%$ & $51,95 \%$ & $94,16 \%$ \\
\hline LDP & $83,81 \%$ & $35,58 \%$ & $36,67 \%$ & $35,34 \%$ & $89,15 \%$ \\
\hline Warna+Bentuk & $89,17 \%$ & $22,56 \%$ & $27,83 \%$ & $23,59 \%$ & $93,38 \%$ \\
\hline
\end{tabular}

\section{KESIMPULAN}

Segmentasi sel darah putih menggunakan metode thresholing pada ranah HSV telah berhasil mensegmentasi sel darah putih dengan akurasi sebesar 68,70\%. Metode segmentasi ini masih belum dapat memisahkan sel darah putih yang menempel dengan baik. Sedangkan klasifikasi sel darah putih dan sel limfoblas metode multilayer perceptron perambatan balik dengan variasi jenis fitur dapat meningkatkan performa sistem klasifikasi.

Dari penelitian yang telah dilakukan, diperoleh performa tertinggi menggunakan fitur correlation, fitur angular second moment, fitur geometri, dan fitur warna dengan akurasi sebesar $91,43 \%$, kemudian presisi 50,63\%, sensitivity 56,67\%. F1 Score 51,95\%, serta specificity $94,16 \%$. Performa ini diperoleh pada learning rate 0,05 dengan iterasi maksimal 1000 kali. Performa klasifikasi yang ditambahkan fitur LBP memiliki akurasi sebesar 90,48\%, presisi $39,01 \%$, sensitivity $41,67 \%$. F1Score 39,33\%, serta specificity 93,49\%. Fitur GLCM yang ditambah fitur LDP memiliki performa akurasi sebesar $85,71 \%$, presisi 44,39\%, sensitivity $40 \%$. F1Score 41,03\%, dan specificity $91,15 \%$. Sedangkan performa klasifikasi dengan fitur 
correlation, fitur angular second moment memiliki performa terendah dengan nilai akurasi sebesar $83,81 \%$, presisi $24,75 \%$, sensitivity $30 \%$. F1 Score 26,81\%, serta specificity $88,67 \%$.

\section{SARAN}

Dari hasil pengamatan yang dilakukan terhadap sistem yang telah dibuat, didapatkan beberapa saran yang mungkin dapat dipertimbangkan untuk penelitian selanjutnya atau penelitian yang berkaitan dengan topik ini. Beberapa saran tersebut adalah penggunaan dataset yang lebih banyak dan seimbang, serta pemilihan arsitektur multilayer perceptron khususnya jumlah node pada hidden layer agar memiliki performa yang lebih baik.

\section{DAFTAR PUSTAKA}

[1] N. Ashton, "Physiology of red and white blood cells," Anaesth. Intensive Care Med., vol. 14, no. 6, pp. 261-266, 2013 [Online]. Available: http://dx.doi.org/10.1016/j.mpaic.2013.03.001

[2] T. TTP, G. N. Pham, J.-H. Park, K.-S. Moon, S.-H. Lee, and K.-R. Kwon, "Acute Leukemia Classification Using Convolution Neural Network in Clinical Decision Support System," Comput. Sci. Inf. Technol. (CS IT), no. October, pp. 49-53, 2017 [Online]. Available: http://airccj.org/CSCP/vol7/csit77505.pdf

[3] M. Z. Othman, T. S. Mohammed, and A. B. Ali, "Neural Network Classification of White Blood Cell using Microscopic Images," vol. 8, no. 5, pp. 99-104, 2017.

[4] A. Setiawan, A. Harjoko, T. Ratnaningsih, E. Suryani, and S. Palgunadi, "Classification of Cell Types In Acute Myeloid Support Vector Machine Classifier," no. Cml, pp. 4549, 2018.

[5] C. V. Angkoso, "Automatic White Blood Cell Segmentation Based on Color Segmentation and Active Contour Model," 2018 Int. Conf. Intell. Auton. Syst., pp. 7276, 2018.

[6] S. K. P. S and V. S. Dharun, "Extraction of Texture Features using GLCM and Shape Features using Connected Regions," vol. 8, no. 6, pp. 2926-2930, 2017.

[7] X. Ding, "Texture Feature Extraction Research Based on GLCM-CLBP Algorithm," vol. 76, no. Emim, pp. 167-171, 2017.

[8] D. Goutam, "Blood Microscopic Images using Supervised Classifier," IEEE Int. Conf. Eng. Technol. (ICETECH), March 2015, Coimbatore, TN, India, no. March, pp. 3-7, 2015.

[9] F. S. Panchal and M. Panchal, "Review on Methods of Selecting Number of Hidden Nodes in Artificial Neural Network," vol. 3, no. 11, pp. 455-464, 2014.

[10] M. N. Khasanah, "Klasifikasi Sel Darah Putih Berdasarkan Ciri Warna dan Bentuk dengan Metode K-Nearest Neighbor (K-NN)," Indones. J. Electron. Instrum. Syst., vol. 6, no. 2, pp. 151-162, 2016. 